\title{
DEBIUTY
}

JOANNA BUŁAWA-HALASZ

Wydział Humanistyczny

Forum Pedagogiczne 2016/1

Uniwersytet Szczeciński

Wpłynęło: 20.11.2015

Szczecin

Zatwierdzono do druku: 13.03.2016

\section{REHABILITACJA SPOLECZNO-ZAWODOWA DOROSŁYCH OSÓB AUTYSTYCZNYCH. WPROWADZENIE DO ZAGADNIENIA}

Streszczenie: Choć autyzm rozpoznawany jest w Polsce od około zo lat, to jednak nie zostały przygotowane rozwiązania systemowe dla dorosłych osób autystycznych po ukończeniu edukacji szkolnej. Liczne raporty przywołane w tekście świadczą o tym, że sytuacja tej grupy jest trudna. Dlatego dużą rolę odgrywają organizacje pozarządowe, dzięki którym dorosłe osoby autystyczne mają szansę na rehabilitację społeczną i zawodową.

Słowa kluczowe: rehabilitacja społeczna, rehabilitacja zawodowa, dorosła osoba autystyczna

\section{Wprowadzenie}

Tekst jest wstępem do zagadnienia rehabilitacji społeczno-zawodowej dorosłych osób autystycznych, bo choć autyzm rozpoznawany jest w Polsce od około 30 lat (co skutkuje tym, że mamy pierwsze zdiagnozowane pokolenie dorosłych osób w Polsce), to jednak nasze państwo nie zdążyło przygotować rozwiązań systemowych dla dorosłych, którzy już ukończyli edukację szkolną ${ }^{1}$. Świadczą o tym nie tylko różne raporty sektora pozarządowego, ale również fakt, że dopiero w 2010 roku w wyniku kilkuletnich działań Porozumienia Autyzm-Polska we współpracy z Parlamentarną Grupą ds. Autyzmu oraz Pełnomocnikiem Rządu ds. Osób Niepełnosprawnych pod koniec grudnia 2009 roku weszły w życie dwa rozporządzenia Ministra Pracy i Polityki Społecznej, które wprowadziły do systemu orzecznictwa o niepełnosprawności i stopniu niepełnosprawności odrębny kod

\footnotetext{
1 Sytuacja dzieci i młodzieży z całościowymi zaburzeniami rozwoju jest inna niż dorosłych z tymi zaburzeniami ze względu na obowiązek nauki i obowiązek szkolny (Ustawa $z$ dnia 7 września 1991 r. o systemie oświaty).
} 
całościowych zaburzeń rozwojowych: $12 \mathrm{C}^{2}$. Określenie „osoby autystyczne” jest stosowane w niniejszym tekście wobec tych, którzy posiadają diagnozę z dwóch kategorii: całościowe zaburzenia rozwojowe (CZR) lub zaburzenia ze spektrum autyzmu (Autism Spectrum Disorders - ASD).

Wiedza na temat specyficznych potrzeb osób autystycznych pomaga w odpowiednim zaplanowaniu i prowadzeniu ich rehabilitacji społeczno-zawodowej.

\section{Charakterystyka osób autystycznych}

W Międzynarodowej Statystycznej Klasyfikacji Chorób i Problemów Zdrowotnych ICD-10 (Manual of the International Statistical Classification of the Diseases and Related Health Problems. 1oth edition) pod kodem F84 widnieje cała grupa zaburzeń zawierających się w nazwie całościowe zaburzenia rozwojowe (CZR). W powyższym ujęciu do CZR zaliczyć można: autyzm dziecięcy, autyzm atypowy, zespół Retta, inne dziecięce zaburzenia dezintegracyjne, zaburzenia hiperkinetyczne z towarzyszącym upośledzeniem umysłowym ${ }^{3}$ i ruchami stereotypowymi, zespół Aspergera, inne całościowe zaburzenia rozwojowe oraz całościowe zaburzenia rozwojowe nieokreślone (ICD-10, 2008).

W 2013 roku Amerykańskie Towarzystwo Psychiatryczne opublikowało nowszą wersję klasyfikacji zaburzeń psychicznych - DSM-5 (Diagnostic and Statistical Manual of Mental Disorders. 5th edition). Zaburzenia ze spektrum autyzmu stanowią w niej nową kategorię, która zastąpiła zaburzenie autystyczne, zespół Aspergera oraz całościowe zaburzenia rozwojowe inaczej nieokreślone (Rybakowski i in. 2014, s. 661). Autorzy powyższej klasyfikacji podjęli decyzję o scaleniu wszystkich wymienionych wyżej jednostek w dużą grupę zaburzeń ze spektrum autyzmu (Autism Spectrum Disorders - ASD) ze względu na trudności diagnostyczne związane z występowaniem w kategorii CZR kilku jednostek o nieostrych granicach rozpoznania oraz coraz częściej występującą praktykę diagnozowania całościowych zaburzeń rozwoju inaczej nieokreślonych (PDD-NOS - Pervasive Developmental Disorder Not Otherwise Specified), a także stwierdzanie u jednej osoby na przestrzeni kilku lat różnych zaburzeń z omawianej kategorii diagnostycznej. Zgodnie z powyższą propozycją do rozpoznania ASD konieczne jest występowanie dwóch osiowych objawów: zaburzeń komunikacji/interakcji społecznych oraz stereotypowych, powtarzalnych zachowań; rozpoznanie jest uzupełniane poprzez dokładną ocenę

2 Patrz: Rozporządzenie Ministra Pracy i Polityki Społecznej z dnia 22 grudnia 2009 r. zmieniające rozporządzenie $w$ sprawie kryteriów oceny niepetnosprawności u osób w wieku do 16 roku życia; Rozporzadzenie Ministra Pracy i Polityki Społecznej z dnia 23 grudnia 2009 r. zmieniajace rozporządzenie w sprawie orzekania o niepetnosprawności i stopniu niepełnosprawności.

3 Obecnie zamiast terminu „upośledzenie umysłowe” stosuje się termin "niepełnosprawność intelektualna”, jednak w tym przypadku jest to oryginalna nazwa zawarta w klasyfikacji. 
funkcjonowania intelektualnego i językowego danego pacjenta (Rybakowski i in. 2014, s. 654-655).

Kryteria diagnostyczne ujęte w obu klasyfikacjach (ICD-10 i DSM-5) wskazują przede wszystkim na występujące w CZR i ASD odchylenia od normy w zakresie interakcji społecznych i komunikacji oraz ograniczony, sztywny i stereotypowy repertuar zachowań, zainteresowań i aktywności. Osoby autystyczne doznają ograniczeń głównie w sferze emocjonalno-społecznej, komunikacyjnej oraz poznawczej (Frith 2008, s. 29-31, 127-147; Jaklewicz 1993, s. 65-67; Pisula 2005, s. 73).

Często z autyzmem współwystępuje niepełnosprawność intelektualna, choć nie ma wśród badaczy zgodności co do tego, jaki odsetek osób autystycznych ona obejmuje (Frith 2008, s. 168; Komender 2009, s. 78; Pisula 2005, s. 50; Smith 2009, s. 278). Ponadto u osób autystycznych w okresie całego życia w 70-100\% przypadków współwystępują inne zaburzenia psychiczne lub neurologiczne, do których należą: tiki, zaburzenia lękowe, fobie specyficzne, zaburzenia obsesyjno-kompulsyjne, zespół lęku społecznego i agorafobia, zaburzenia lękowe uogólnione, przetrwały lęk separacyjny, zaburzenia lękowe z napadami lęku, epizody depresji, zaburzenia dwubiegunowe, zaburzenia snu oraz zespół nadpobudliwości psychoruchowej z deficytem uwagi (Rybakowski i in. 2014, s. 656-657).

\section{Rehabilitacja społeczna i zawodowa dorosłych osób autystycznych}

Istnieje bardzo silne powiązanie pomiędzy rehabilitacją społeczną i zawodową powodzenie rehabilitacji społecznej jest warunkiem powodzenia zawodowej i odwrotnie, a do aktywności zawodowej osób niepełnosprawnych przywiązuje się wagę jako do wskaźnika aktywności społecznej w ogóle, przynoszącej satysfakcję ze społecznego funkcjonowania (Gąciarz i in. 2008, s. 72).

Osoby autystyczne z racji swej niepełnosprawności podlegają Ustawie $z$ dnia 27 sierpnia 1997 r. o rehabilitacji zawodowej i społecznej oraz zatrudnianiu osób niepełnosprawnych ${ }^{4}$. Według powyższego aktu rehabilitacja osób niepełnosprawnych oznacza „zespół działań, w szczególności organizacyjnych, leczniczych, psychologicznych, technicznych, szkoleniowych, edukacyjnych i społecznych, zmierzających do osiągnięcia, przy aktywnym uczestnictwie tych osób, możliwie najwyższego poziomu ich funkcjonowania, jakości życia i integracji społecznej” (art. 7.1). Jej składowe stanowią rehabilitacja zawodowa i społeczna.

Rehabilitacja zawodowa ma ułatwić osobie z niepełnosprawnością uzyskanie i utrzymanie odpowiedniego zatrudnienia, a także awans zawodowy w wyniku korzystania z poradnictwa i szkolenia zawodowego oraz pośrednictwa pracy (art. 8.1), społeczna zaś ma umożliwić uczestnictwo w życiu społecznym poprzez

${ }^{4}$ Od października ur. zaczęła obowiązywać Ustawa $z$ dnia 6 lutego 2015 r. o zmianie ustawy o rehabilitacji zawodowej i społecznej oraz zatrudnianiu osób niepełnosprawnych, która nie zmieniła jednak znaczenia pojęć rehabilitacji społecznej i zawodowej. 
wyrabianie u osoby niepełnosprawnej zaradności osobistej, umiejętności samodzielnego wypełniania ról społecznych, pobudzanie aktywności społecznej oraz likwidację barier (architektonicznych, urbanistycznych, transportowych, technicznych, w komunikowaniu się i dostępie do informacji), a także kształtowanie w społeczeństwie właściwych postaw i zachowań, sprzyjających integracji z osobami niepełnosprawnymi (art. 9.1).

Praca zawodowa odgrywa w życiu człowieka wiele funkcji: oprócz materialnych, na które składa się m.in. dostarczanie niezbędnych środków do zaspokojenia potrzeb materialnych (Majewski 2011, s. 92), również wiele pozamaterialnych (Giddens 2004, s. 396). Wykonywanie jej zgodnie z zainteresowaniami oraz możliwościami przyczynia się do rozwoju osobowości człowieka, stanowi źródło radości i satysfakcji, a przez to umożliwia samorealizację, wpływa na psychofizyczny rozwój, wyzwala inicjatywę i twórczą aktywność myślową, dostarcza przeżyć estetycznych. Bardzo często nadaje życiu sens oraz wpływa na jego kształt. Jej wykonywanie wyznacza miejsce człowieka w społeczeństwie, wzmacnia jego poczucie wartości i przydatności, co w przypadku osób niepełnosprawnych może mieć szczególne znaczenie. Stanowi też czynnik rozwijający więź społeczną - sprzyja zaspokajaniu potrzeby kontaktów z innymi ludźmi (Bidziński 2011, s. 112). Ponadto zapewnienie pracy zawodowej w dużym stopniu przyczynia się do społecznej integracji i zapobiega wykluczeniu lub marginalizacji osób niepełnosprawnych (Majewski 2011, s. 92; Ostrowska i in. 2001). U osób z niepełnosprawnością brak aktywności zawodowej wpływa niekorzystnie na określone aspekty poczucia jakości życia (Szczupał 2006).

W Polsce nie działa żaden system służący przygotowaniu do dorosłego życia czy wsparciu dorosłych osób autystycznych w podejmowaniu pracy (Ramik-Mażewska 2008, s. 30). Wszelkie duże przedsięwzięcia z zakresu rehabilitacji zawodowej i społecznej dokonywały się do tej pory tylko dzięki rodzinom osób autystycznych oraz trzeciemu sektorowi, a dokładnie stowarzyszeniom i fundacjom ukierunkowanym na pomoc osobom autystycznym, np. Fundacji SYNAPSIS, Fundacji Wspólnota Nadziei, Krajowemu Towarzystwu Autyzmu, Stowarzyszeniu Pomocy Osobom Autystycznym z Gdańska, Dolnośląskiemu Stowarzyszeniu na rzecz Autyzmu z Wrocławia, Stowarzyszeniu na rzecz Autyzmu „Uczymy się żyć razem” z Opola, Stowarzyszeniu św. Celestyna z Mikoszowa, Stowarzyszeniu Pomocy Osobom Autystycznym „Dalej razem” z Zielonej Góry, Stowarzyszeniu na rzecz Osób z Autyzmem ProFUTURO z Poznania i wielu innym ${ }^{5}$. Tak duża liczba organizacji

\footnotetext{
5 Jest to część członków Porozumienia Autyzm-Polska, które jest związkiem organizacji pozarządowych, pracujących na rzecz dzieci i dorosłych osób z autyzmem i pokrewnymi zaburzeniami oraz ich rodzin. Jego zebranie założycielskie miało miejsce 6 grudnia 1997 r. w Gdańsku. W lutym 1998 r. w Warszawie 27 organizacji pozarządowych podpisało deklarację programową. Obecnie w skład Porozumienia Autyzm-Polska wchodzi ok. 50 organizacji świadczących pomoc osobom autystycznym i ich rodzinom (Lista członków...).
} 
zajmujących się rehabilitacją społeczno-zawodową osób autystycznych również świadczy o pewnej niewydolności struktur państwowych w zakresie udzielania im pomocy.

Spośród kilku tysięcy osób autystycznych na rehabilitację społeczną i zawodową ma szansę najwyżej kilkaset, i to w miejscach skupionych wokół prężnie działających organizacji sektora pozarządowego. Należy tutaj wspomnieć o placówkach pionierskich w skali kraju. Jedną z nich jest założone przez Fundację SYNAPSIS przedsiębiorstwo społeczne Pracownia Rzeczy Różnych w Wilczej Górze pod Warszawą. Daje ono zatrudnienie i zapewnia terapię 24 dorosłym osobom z autyzmem. Pracują oni w pracowniach: stolarskiej, ceramicznej, prac biurowych i papieru, rękodzieła artystycznego, ogrodniczej oraz eksperymentalnej (Buława-Halasz 2011; Pracownia...). Drugim miejscem jest Farma Życia, założona przez Fundację Wspólnota Nadziei w Więckowicach pod Krakowem. Jest to ekologiczne gospodarstwo rolne i rodzaj wspólnoty wiejskiej - miejsce stałego pobytu, pracy, terapii i rehabilitacji dla dorosłych osób autystycznych (Buława-Halasz 2011; Farma Życia...).

W miejscowościach, w których nie działa fundacja ani stowarzyszenie na rzecz osób autystycznych, a dorośli nie mają zapewnionej żadnej rehabilitacji czy terapii - po opuszczeniu systemu szkolnego stają się „obywatelami niewidzialnymi”, nie mają możliwości zarobkowania, samodzielnego mieszkania czy uczestniczenia w życiu społeczności lokalnej. Świadczą o tym liczne raporty, które są sporządzane przez różne organizacje pozarządowe. Wymienić tutaj można między innymi: Raport z badania pilotażowego realizowanego $w$ ramach projektu pt. Wsparcie osób $z$ autyzmem (IV-X 2009), Raport końcowy $z$ ewaluacji projektu pt. Wsparcie osób $z$ autyzmem (II 2009 - III 2010), Raport 2004. Sytuacja dorostych osób z autyzmem $w$ Polsce, Raport 20o8. Sytuacja osób $z$ autyzmem w województwie zachodniopomorskim oraz największy Raport 2013. Autyzm - sytuacja dorostych.

Z powyższych opracowań wynika, że sytuacja dorosłych osób autystycznych i ich rodzin jest trudna, naruszane są ich prawa obywatelskie zagwarantowane w konstytucji i szeregu aktów międzynarodowych, a także prawa osób niepełnosprawnych, wynikające z Konwencji o prawach osób niepełnosprawnych. Naruszenia te mają charakter systemowy, nie incydentalny czy indywidualny, i związane są z charakterem niepełnosprawności.

W zakresie rehabilitacji społeczno-zawodowej dorosłych osób autystycznych brakuje w szczególności (Raport 2013... s. 252-254):

- danych na temat liczebności dorosłych osób autystycznych na terenie gmin i powiatów oraz ich sytuacji i potrzeb,

- placówek aktywności dziennej oraz innych form rehabilitacji społecznej i zawodowej dostosowanych do specyfiki niepełnosprawności, jaką jest autyzm,

- placówek całodobowej opieki okresowego pobytu i innych form wsparcia rodzin dorosłych osób autystycznych, skracających okres zdolności rodziny do opieki nad dorosłą osobą autystyczną, 
- małych placówek całodobowego stałego pobytu dla dorosłych, dostosowanych do specyfiki niepełnosprawności, jaką jest autyzm,

- działań podejmowanych przez jednostki samorządu terytorialnego i władze państwowe na rzecz poprawy sytuacji dorosłych osób autystycznych. Wiedza urzędników na temat specyfiki tego zaburzenia jest ograniczona, nie są zatem podejmowane kroki zmierzające do zmniejszenia dyskryminacji osób autystycznych. Większość starań podejmowana jest przez organizacje pozarządowe w warunkach braku stabilności finansowej i na zasadach krótkookresowych projektów, co znacznie utrudnia lub uniemożliwia prowadzenie planowej działalności.

Szczegółowe dane zamieszczone w Raporcie 2013... ujawniły dramatyczną sytuację, w jakiej znajdują się osoby autystyczne, oraz obnażyły niedostosowanie systemu pomocy do ich potrzeb, zwłaszcza w części mającej na celu aktywizację zawodową i społeczną, z której korzysta jak na razie niewielka liczba osób. Rodzice najczęściej mówili o: edukacji, terapii i rehabilitacji, usamodzielnianiu, uspołecznianiu, opiece doraźnej oraz ośrodkach dziennego pobytu zapewniających opiekę, rehabilitację oraz aktywizację zawodową. Zgłaszane potrzeby są ogromne, a do ich zaspokojenia potrzebne są zmiany w całym systemie pomocy (od ochrony zdrowia poprzez m.in. edukację, pomoc społeczną, aktywizację zawodową aż po politykę dotyczącą mieszkalnictwa). Obecny system nie zaspokaja w sposób satysfakcjonujący żadnej $\mathrm{z}$ nich.

Wszelkie działania rehabilitacyjne związane z osobami niepełnosprawnymi mają na celu przeobrażenie ich w jednostki samowystarczalne i przydatne społeczeństwu oraz przywrócenie im pełni życia, jednak - jak się okazuje w praktyce polskie ustawodawstwo nie normuje zagadnień rehabilitacyjnych w zadowalający sposób. Teresa Żółkowska wskazuje na przedkładanie rehabilitacji zawodowej nad inne jej rodzaje oraz na połączenie w jedno rehabilitacji zawodowej i społecznej, co powoduje, że osoby znajdujące się poza okresem aktywizacji zawodowej mają nieunormowaną sytuację. Autorka zwraca uwagę na rozwiązania, które należało przyjąć już w fazie projektowania ustaw, a mianowicie przepisy z ustawy o zatrudnieniu i rehabilitacji zawodowej mówiące o odpłatnej pracy niepełnosprawnych powinny być zawarte w Kodeksie pracy, a przepisy stanowiące o przeciwdziałaniu bezrobociu tej grupy - w ustawie o zatrudnieniu i przeciwdziałaniu bezrobociu (Żółkowska 2004, s. 189).

\section{Podsumowanie}

Dostępność pracy dla osób niepełnosprawnych jest jedną z trzech sfer - obok życia intymnego i godziwych form mieszkalnictwa - charakteryzujących się zewnętrznymi ograniczeniami, które stają na drodze do dorosłości i wpływają bezpośrednio na jakość życia (Dąbrowska 2003). 
Zrozumienie specyfiki doznawanych przez osoby autystyczne trudności pozwala na dostosowanie się do ich potrzeb i skuteczniejsze planowanie rehabilitacji społeczno-zawodowej. Do tego potrzebne są również dane na temat faktycznej liczby osób autystycznych, skali i rodzaju ich potrzeb. Nie ma jednak, niestety, żadnego mechanizmu pozwalającego obecnie na uzyskanie tych informacji. W Polsce przyjmuje się - bazując na szacunkowych obliczeniach sporządzonych w oparciu o wskaźniki epidemiologiczne z państw Europy Zachodniej - że jest ich dziesięć tysięcy, ale liczba ta stale rośnie. Dane zbiera jedynie System Informacji Oświatowej, i dotyczą one dzieci i młodzieży objętych edukacją. Natomiast na temat dorosłych osób autystycznych ani system orzecznictwa, ani system pomocy społecznej czy ochrony zdrowia nie mają żadnych zbiorczych zestawień. Przy ich braku ocena skali i rodzaju potrzeb dorosłych osób autystycznych, stopnia ich zaspokojenia i dostosowania wsparcia do specyfiki tej niepełnosprawności są niemożliwe.

\section{Bibliografia}

Bidziński K. (2011). Aktywizacja zawodowa i społeczna integracja dorosłych osób $z$ niepetnosprawnościa intelektualna - przykłady dobrej praktyki z wybranych krajów Unii Europejskiej. W: Cytowska B. (red.). Dorośli z niepełnosprawnością intelektualna w labiryntach codzienności. Analiza badań - krytyka podejść propozycje rozwiazann. Toruń: Wydawnictwo Adam Marszałek.

Buława-Halasz J. (2011). Aktywność zawodowa dorosłych osób z autyzmem w Polsce. W: Żółkowska T., Konopska L., Szarkowicz D. (red. nauk.). Uszkodzenie, niepełnosprawność, upośledzenie - aspekty teoretyczne i praktyczne $w$ pedagogice XXI wieku, t. 8. Szczecin: Wydawnictwo Uniwersytetu Szczecińskiego.

Dąbrowska A. (2003). Pytania o możliwości bycia dorosłym z niepełnosprawnością intelektualną we wspótczesnym świecie. W: Rzedziecka K., Kobylańska A. (red.). Dorosłość, niepełnosprawność, czas współczesny. Na pograniczach pedagogiki specjalnej. Kraków: Oficyna Wydawnicza Impuls.

Farma Życia. Fundacja Wspólnota Nadziei, www.farma.org.pl i http://www.farma. org.pl/dzialalnosc/gospodarstwo-ekologiczne.html (otwarty 22.03.2016).

Frith U. (2008). Autyzm. Wyjaśnienie tajemnicy, tłum. Hernik M., Krajewski G. Gdańsk: Gdańskie Wydawnictwo Psychologiczne.

Gąciarz B., Ostrowska A., Pańków W. (2008). Integracja społeczna i aktywizacja zawodowa osób niepetnosprawnych zamieszkałych $w$ małych miastach i na terenach wiejskich. Uwarunkowania sukcesów i niepowodzeń. Raport z badań. Warszawa: IFiS PAN.

Giddens A. (2004). Socjologia. Warszawa: Wydawnictwo Naukowe PWN.

ICD-10. (2008). Międzynarodowa Statystyczna Klasyfikacja Chorób i Problemów Zdrowotnych. Rewizja dziesiąta. Tom I. World Health Organization, Centrum Systemów Informacyjnych Ochrony Zdrowia; http://www.csioz.gov.pl/src/files/ klasyfikacje/ICD1oTomI.pdf (otwarty 10.11.2015). 
Jaklewicz H. (1993). Autyzm wczesnodziecięcy. Diagnoza, przebieg, leczenie. Gdańsk: Gdańskie Wydawnictwo Psychologiczne.

Komender J. (2009). Sprawność intelektualna dziecka autystycznego. W: Bryńska A., Komender J., Jagielska G. Autyzm i zespół Aspergera. Warszawa: Wydawnictwo Lekarskie PZWL.

Lista członków Porozumienia Autyzm-Polska, http://synapsis.org.pl/autyzm/autyzm-polska/organizacje-zrzeszone (otwarty 10.11.2015).

Majewski T. (2011). Problem zatrudnienia osób z niepetnosprawnością intelektualną. W: Cytowska B. (red.). Dorośli z niepełnosprawnościa intelektualna w labiryntach codzienności. Analiza badań - krytyka podejść - propozycje rozwiązań. Toruń: Wydawnictwo Adam Marszałek.

Ostrowska A., Sikorska J., Gąciarz B. (2001). Wpływ transformacji społeczno-ekonomicznej na sytuacje i aktywność osób niepetnosprawnych w latach 9o. W: Kawczyńska-Butrym Z. (red.). Problemy opieki i środowisko życia osób niepetnosprawnych. Olsztyn: Olsztyńska Szkoła Wyższa.

Pisula E. (2005). Małe dziecko z autyzmem. Gdańsk: Gdańskie Wydawnictwo Psychologiczne.

Porozumienie Autyzm-Polska, http://autyzmwpolsce.pl/autyzm-polska/o-porozumieniuautyzm-polska (otwarty 10.11.2015).

Pracownia Rzeczy Różnych. Fundacja Synapsis, www.pracowniasynapsis.pl (otwarty 22.03.2016).

Ramik-Mażewska I. (2008). Sytuacja prawna dzieci i osób dorosłych z autyzmem w Polsce na tle prawa europejskiego. W: Wlazło M. (red.). Żyć z autyzmem. Dobro osoby z autyzmem - naukowe, społeczne i prawne aspekty rehabilitacji. Szczecin: Krajowe Towarzystwo Autyzmu Oddział w Szczecinie.

Raport 2004. Sytuacja dorosłych osób $z$ autyzmem w Polsce. Warszawa: Fundacja Synapsis.

Raport 2005. Prawa osób z niepełnosprawnościa intelektualną. Dostęp do edukacji i zatrudnienia. Warszawa: Polskie Stowarzyszenie na rzecz Osób z Upośledzeniem Umysłowym.

Raport 2008. Sytuacja osób z autyzmem w województwie zachodniopomorskim. Szczecin: Krajowe Towarzystwo Autyzmu.

Raport 2013. Autyzm - sytuacja dorosłych. Warszawa: Fundacja Synapsis, Instytut Rozwoju Służb Społecznych, http://autyzmwpolsce.pl/pliki/Raport_2013_ Autyzm.pdf (otwarty 10.10.2014).

Raport końcowy z ewaluacji projektu pt. Wsparcie osób z autyzmem (II 2009 - III 2010), http://www.efs.gov.pl/analizyraportypodsumowania/baza_projektow_badawczych_efs/documents/raport_koncowy_osoby_z_autyzmem_na_rynku_ pracy_mpips25032011_.pdf (otwarty 11.10.2013).

Raport $z$ badania pilotażowego realizowanego $w$ ramach projektu pt. Wsparcie osób $z$ autyzmem (IV-X 2009), http://www.autyzm-dorosli.pl/pl/aktualnosci/1024. html (otwarty 8.05.2011). 
Rozporzadzenie Ministra Pracy i Polityki Społecznej z dnia 23 grudnia 2009 r. zmieniajace rozporzadzenie $w$ sprawie orzekania o niepełnosprawności i stopniu niepełnosprawności (Dz.U. 2009, nr 224, poz. 1803).

Rybakowski F., Białek A., Chojnicka I., Dziechciarz P., Horvath A., Janas-Kozik M., Jeziorek A., Pisula E., Piwowarczyk A., Słopień A., Sykut-Cegielska J., Szajewska H., Szczałuba K., Szymańska K., Urbanek K., Waligórska A., Wojciechowska A., Wroniszewski M., Dunajska A. (2014). Zaburzenia ze spektrum autyzmu epidemiologia, objawy, współzachorowalność i rozpoznawanie. „Psychiatria Polska”, 48 (4), s. 653-665; http://www.psychiatriapolska.pl/uploads/images/ PP_4_2014/653Rybakowski_PsychiatrPol2014V48i4.pdf (otwarty 10.11.2015).

Smith D.D. (2009). Pedagogika specjalna. Podręcznik akademicki, t. 1. Warszawa: Wydawnictwo Naukowe PWN.

Szczupał B. (2006). Wybrane aspekty poczucia jakości życia bezrobotnych osób niepełnosprawnych. W: Palak Z. (red.). Jakość życia osób niepetnosprawnych i nieprzystosowanych społecznie. Lublin: Wydawnictwo Uniwersytetu Marii Curie-Skłodowskiej.

Ustawa z dnia 27 sierpnia 1997 r. o rehabilitacji zawodowej i społecznej oraz zatrudnianiu osób niepetnosprawnych (Dz.U. 1997, $\mathrm{nr}$ 123, poz. 776).

Ustawa z dnia 6 lutego 2015 r. o zmianie ustawy o rehabilitacji zawodowej i społecznej oraz zatrudnianiu osób niepełnosprawnych (Dz.U. 2015, poz. 493).

Ustawa z dnia 7 września 1991 r. o systemie oświaty (Dz.U. 1991, nr 95, poz. 425).

Wiatrowski Z. (2005). Podstawy pedagogiki pracy. Bydgoszcz: Wydawnictwo Akademii Bydgoskiej im. Kazimierza Wielkiego.

Żółkowska T. (2004). Wyrównywanie szans społecznych osób z niepełnosprawnością intelektualna. Uwarunkowania i obszary. Szczecin: Oficyna In Plus.

\title{
SOCIAL AND VOCATIONAL REHABILITATION OF ADULT AUTISTIC PEOPLE. INTRODUCTION TO THE ISSUE
}

\begin{abstract}
Although autism has been diagnosed in Poland for about 30 years, no systemic solutions for autism in adults who have completed school education have been developed so far. Numerous reports cited in the text bear witness to autistic adults' difficult situation. That is why NGOs play a large role as they provide autistic adults with a chance of social and vocational rehabilitation.
\end{abstract}

Key words: social rehabilitation, vocational rehabilitation, adult autistic person

Joanna Buława-Halasz - doktor w Katedrze Pedagogiki Specjalnej Instytutu Pedagogiki na Uniwersytecie Szczecińskim. Współredaktorka: Disability: premises and conclusions (2015); Niepełnosprawność. Interpretacje teoretyczne i praktyczne (2015); Niepełnosprawność w spirali naukowych rozważań (2015). Adres do korespondencji: Instytut Pedagogiki US, ul. Ogińskiego 16/17, 71-431 Szczecin. 